RSR: Reference Services Review. 1982, v.10, no.3, p. 23 -29.

ISSN: 0090-7324

Weblink to journal.

(C)1982 Pierian Press

CURRENT SURVEYS

\title{
Reference Sources in Photography
}

\section{Eleanor S. Block}

\section{Introduction}

While the spread of mass media culture in the United States has often been measured in terms of the number of television sets in each home, the camera and the photograph have been almost as pervasive. Once the province of the professional photographer or the special studio, cameras of the same type are found today in all but a very few homes in the United States. Even rarer would be a home without its collection of photographs to record the family's events, joys, triumphs and tragedies as well as the everyday mundane record of events.

To some, photography is a simple and pleasurable hobby; to others it is a profession, a science or a technology. More importantly, photography has attained well deserved recognition as a true member of the fine arts. All of these varied aspects of photography are reflected in the reference sources chosen for this survey. It should be noted that due to the multifarious nature of photography, many of the works in the survey do not have the word "photography" in their title and in several instances the subject heading assigned by the Library of Congress is "Art" rather than "Photography."

This survey has been divided into eight sections: Bibliographies, Indexes, Directories, Dictionaries, Handbooks and Manuals, Collectors and Collecting, Yearbooks and Miscellaneous. All of the sources in this selective bibliography have been published within the past decade and are in print.

\section{Bibliographies}

In 1962 Albert Boni edited a bibliography of photographic literature covering the period 1927 - 1960 which became and remains a classic in its field. A second volume, Photographic Literature, $1960-1970^{1}$ was published in 1972. It contains approximately 2,900 alphabetically arranged subject headings, more than twice the amount of the earlier volume even though it covers a shorter time span. This work indexes over 160 international journals, proceedings, abstracts, books and technical reports on photographic techniques, processes, theory, chemistry, physics, apparatus, chemicals, biography, history, etc. It is a classic addition to the field of photographic research. 
Photography is very much an international interest. Much of the literature has been published in Germany, France and Great Britain as well as the United States. German Photographic Literature $1839-1978^{2}$ is a more complete bibliography of independently published German language photographic literature from Germany, Austria, Switzerland and other places since 1839. Included are books, periodicals, exhibition catalogs, dissertations, university publications and offprints. The 11,640 title entries have been divided into five main classifications: General, Technology, On Photographs, Visual and Company Publications. Within these groupings the arrangement is chronological and then alphabetical by author or title. Some peripheral areas of photography such as photogrammetry and photometry methods have been included. Only the title, preface, introduction and subject headings are in both German and English while the text is solely in German. This is another of G.K. Saur's uniformly excellent bibliographies.

Art, Design, Photo ${ }^{3}$ is a British annual publication which is a one-man, non-computerized bibliography of books, catalogs and articles on modern art, graphics and photography. Editor Alexander Davis tends to select the entries by personal whim and therefore the indexing is selective rather than comprehensive. The emphasis is on British materials. About 50-75 periodicals are indexed per issue. The latest issue, which covers 1975, lists about ten photographic journals. The 1976 issue is now in preparation. The index to periodicals section is arranged by classification and articles on various photographers are included within an artists list which is arranged alphabetically. The strength of this publication is the care with which the materials have been selected as well as the emphasis on otherwise little known items.

The Smithsonian Institution Press has published Arts in America: A Bibliography, ${ }^{4}$ a landmark work, for the Archives of American Art. Only available as a set, it contains three volumes and an additional index volume covering such topics as the art of native Americans, architecture, design, arts of the west, painting, graphic arts, and so on. A complete review of this set appears in $R S R$ 9:3 (1981), 73-75.

Volume 3 is entitled Photography, Film, Theater, Dance, Music.... The approximately 75-page section devoted to photography was prepared by noted photo-historian Beaumont Newhall. This section consists of materials on history, criticism, collections, exhibitions and techniques divided into such classifications as reference works, collections of photographs, and criticism and about 170 entries under individual photographers. Each of these entries contains bibliographic data and a description of its content as well as some critical evaluation. This volume also contains a combined list of serials, dissertations, a description and review of American photography journals, a chronology, and an inventory of art holdings, including photography, in major universities and galleries in the United States.

The Rochester Institute of Technology's Graphic Arts Research Center prepares many bibliographic and other works of note in the field. A Selected Bibliography on Photographic Conservation $^{5}$ covers materials published between January 1975 and December 1978. All of the items are in English and have been chosen from photography or conservation journals. Each item includes an abstract number, title, author, source and an abstract. The abstract number is useful for ordering reprints which are available at nominal cost from the institute. There is no index.

Another of the Institute's publications is the Bibliography of Photographic Processes in Use before 1880: Their Materials, Processing and Conservation. ${ }^{6}$ This work emphasizes such historically significant processes as daguerrotypes and salted paper prints. The citations were culled mainly from photographic journals published pre-1880 in English, although 15 French and German periodicals and 15 general and scientific periodicals have also been cited. Each entry 
includes an abstract number, bibliographic information, keywords, source and other journal locations for the cited item. There is an author and a keyword index.

\section{Indexes}

There is no good current or retrospective index devoted solely to periodicals in photography. Selected journals are indexed in some of the sources mentioned in the Bibliographies section and the Index Section of this reference survey. Each of the following works has its uses and limitations.

Art Index ${ }^{7}$ is another of the H.W. Wilson's carefully edited periodical indexes. From its beginning in 1929 it has indexed both domestic and foreign publications in art, archeology, architecture and other fine arts such as photography. It also indexes yearbooks and museum publications. The arrangement, as in all the Wilson indexes, is by subject/author. Eight journals devoted exclusively to photography such as the British Journal of Photography, Camera, Creative Camera and Photographic Review are indexed at present.

The Index to Articles on Photography ${ }^{8}$ represents a great hope to librarians, researchers and scholars. Begun as an annual volume in 1977 it indexed 98 photographic journals published worldwide in its 1978 edition. The indexing is arranged in several classifications of which the artists section is the largest. Each entry includes title, author, source, volumes, pagination and additional notes. Other classifications are artist/group portfolios, bibliographies, book reviews, geographical, exhibitions, galleries, museums, history, processes, etc. There is a combined author and subject index. The first two volumes were done by the Visual Studies Workshop Press of Rochester. Due to financial difficulties, its publication has been turned over to G.K. Hall which plans to publish the 1979 edition in 1983. This is a much needed series, even though its multi-classification arrangement should be simplified.

An index to reproductions found in 80 major photography books and printed exhibition catalogs is Photography Index: A Guide to Reproductions, ${ }^{9}$ compiled by Pamela J. Parry. It is a tool for locating photographic reproductions from the 1820 s to 1970 in collective photography books, all of which are in English. It includes artistic, journalistic and documentary photographs done mostly by professional photographers. The book is divided into three sections. The first is a chronological list of works that are anonymous. This includes title, date and source. Section II is an index by photographers. It includes dates, alternative names, nationality, title, type of media used and source. The last major section is a subject and title index.

Photography Books Index: A Subject Guide to Photoanthologie ${ }^{10}$ not only has a similar title, it includes the same type of data as Photography Index, although its emphasis is on the subject of the photography rather than the photographer. Indexed are 23 books, most of which are survey histories of photography, as well as the Time-Life series nos. 1--6. ${ }^{11}$ The selection of these 23 books was based on the list of books found in Photography Market Place (see Directories) and on a survey of holdings in various New York State, Chicago and Memphis public and academic library collections. It too has three sections: photographers, subjects, and portraits. 


\section{Directories}

Many of the directories in this section are actually market directories for the selling and marketing of photographs and photographic talents. They are almost exact replicas of the style of Writer's Digest except that they are aimed at the amateur and professional photographer. They emphasize the business aspect of photography rather than the artistic.

Photographer's Market ${ }^{12}$ began in 1977. In its 1981 edition it listed 1,616 markets and opportunities for the freelance photographer. Updated annually, it contains information on how to be a freelancer. Listings of advertising agencies, AV firms, businesses, calendar and poster firms, trade journals, association publications and consumer publications which purchase photographs from freelancers are given. Each of the entries include name, address, telephone number, contact person, description of what is purchased, payment, model release requirements and size, color and negative specifications. There is also a list of galleries, workshops, journals and college programs of interest to photographers. A Writer's Digest publication, it supercedes in part Artist's and Photographer's Market. This is the best and most complete of the market directory reference sources.

Another in a series of market place books published by Bowker such as Literary Market Place, Magazine Industry Market Place, Information Industry Market Place and Fine Arts Market Place is Photography Market Place: The Complete Source Book for Still Photography. ${ }^{13}$ Its 1977 edition seems to be the last according to a publisher's spokesperson who said that no other edition is in progress or planned at the moment. Its scope is somewhat different than Photographer's Market. It is not only a guide to picture buyers, but lists film laboratories, equipment manufacturers and distributors, publishers, reference books, grants, prizes, museums, etc. The arrangement is geographical. Each entry includes name, address, telephone number, brief descriptive data and a contact person.

From the New York Institute of Photography comes the third of the market directories. The bulk of Freelance Photographer's Handbook ${ }^{14}$ is a market guide to picture agencies, consumer periodicals, calendar and poster publishers, book publishers, equipment manufacturers, etc. The information is brief: name, address, telephone number, payment and a one line description of photo needs. About 30 of its 140 pages are devoted to general information for freelance photographers on what to sell, what equipment to use and whom to contact. About 1,000 buyers are listed. One feature of particular interest is the vast amount of tips scattered throughout the entries. This is the least expensive of the market place tools and as such may be recommended for smaller collections and to amateur photographers for personal use.

The Writer's and Photographer's Guide: Travel, Leisure, Sports, Outdoors, Nature ${ }^{15}$ is the last of the mainly photography market books in this survey. It is a specialized guide to the areas noted in its subtitle. It includes a list of American and Canadian magazines classified by such subjects as mountaineering, running and bicycling, a detailed description of the travel sections of newspapers, and a list of travel offices. A section called "Writer's and Photographer's Almanac" is a compendium of information on national holidays in other countries, festivals, national parks and Jewish holidays. A unique feature is its list of magazine editors who will accept simultaneous submissions. Finally, there is a list of over 800 freelancers whose specialty is sports and leisure. This is arranged geographically and includes name, address, availability for travel and magazine titles in which their work has appeared. 
Since the data in this section are submitted by the photographers, they are prone to error or bias.

Working Press of the Nation ${ }^{16}$ also contains a list of photographers in its annual series which has been published since 1949. Feature Writers and Photographers Directory is the title of Volume 4. The section devoted to photographers is divided into two parts: freelance photographers and an index of photographers arranged by subject specialty. These parts include name, mailing address, professional affiliations, specialties of photographer arranged in order of importance and titles of publications in which work has appeared. Again, the information is compiled from questionnaires and is open to error.

Literary Market Placed ${ }^{17}$ thought of primarily as the premier annual directory of the American book publishing trade, also has several types of information of interest to photography reference. It contains a list of American photographers who will take assignments all over the United States. The entries include name, address, telephone, brief descriptions of types of photography, and photo and picture sources arranged by category.

The most attractive and visually stunning book in this entire survey is the American Showcase of Photography, Illustration and Graphic Design. ${ }^{18}$ While it too lists photographers and their specialties, it is primarily a pictorial work which almost incidentally is a very useful and valuable reference tool. Known alternatively as American Showcase of Photography and Illustration, its main section is a list of photographers arranged into six geographic regions of the United States: New York metropolitan area, northeast, southwest, southeast, midwest and west coast. Each photographer is represented by a full page of one to six full color, slick paper photos representative of the contributor's work in illustration, advertising and graphic design. Many groups and studios rather than individuals appear. On each page is the name, address, photographic specialties, list of clients, corporations and publications for whom work has been done, an agent and telephone number. Some descriptions of the type of work and an occasional biographical sketch are included. A Reference Section has telephone listings of over 5,000 photographers, illustrators, graphic designers, stock photographers and companies. A final list of photographers divided into eight categories, advertising, corporate (annual reports), editorial, still life, food, photo illustration, fashion/beauty, and others completes the volume. The high quality of this source is evident throughout.

Max and Tina Lent are the editors of a directory titled Photography Galleries and Selected Museums: A Survey and International Directory. ${ }^{19}$ A major portion of this reference work is the actual reproduction of questionnaires sent to museums and galleries in the United States that were polled concerning their interest in photography. Arranged geographically, these surveys include address, type of work exhibited, shipment procedures, time span of collection, gallery space, commission policies, publicity, curator's name, hours, institution affiliation and deadline. Since a number of the questionnaires are hand written, a few are almost illegible. The reference also contains an alphabetic and geographic list of pertinent museums and galleries in the United States and similar lists for Canada and Europe.

Gadneys Guide to 1800 International Contests, Festivals \& Grants in Film \& Video, Photography, TV-Radio Broadcasting, Writing, Poetry, Play writing and Journalism ${ }^{20}$ contains almost 150 pages devoted to contests in photography in over 59 categories that are indexed by event, sponsor and subject. The contests are classified into such categories as Arts \& Crafts, Fairs \& Festivals, Exhibitions, Galleries, Regional Photography, Travel, Underwater, Women and Photojournalism.

A common question concerns the location of free photographs and how to obtain them. The answer can be found in Free Stock Photography Directory. ${ }^{21}$ Arranged by issuing agency, the 
information includes address, telephone number, contact person, type of photographs available, model release information, format, office hours, credit line requirements and any special instructions. Most of the photographs, some of which must be returned, are supplied by chambers of commerce, tourist offices or industrial equipment manufacturers. The subjects range from aerial views, clam digging and word processing equipment to zoos. There is a subject and a geographic index.

The last of the directory reference sources in this survey is a unique work. Produced by the Photography Media Institute of New York, the Photography A-V Program Directory ${ }^{22}$ provides basic information on more than 3,300 audio visual programs relevant to still photography. These include slides, tape, film, microformat, etc. The individual photographers part contains data concerning subject, format, title, whether black-and-white or color, availability, price description and source. A section called "Interchanges" includes materials on photography in dialogue form, e.g., panels or debates. Other sections cover the historical, technological and theoretical aspects of the subject. The book includes a 57-page glossary of photography and A-V related terms as well as separate name, source and subject indexes. Its value to teachers, workshop personnel and to selectors of audio-visual materials is evident, although the materials are not reviewed.

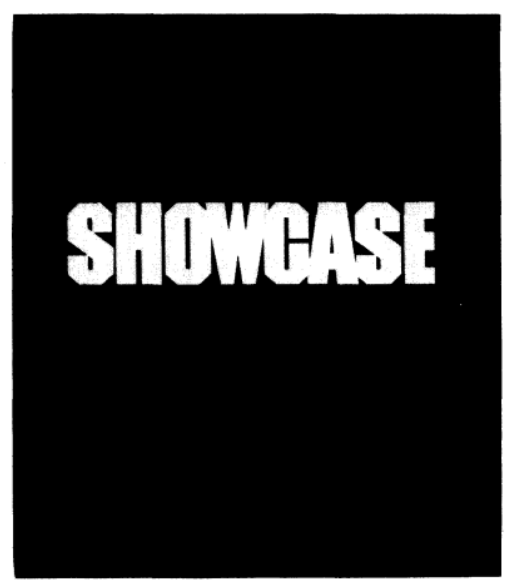

\section{Dictionaries}

The Running Press of Philadelphia has lately made a specialty of printing glossaries of terms in such faddish fields as martial arts and astrology. The Running Press Glossary of Photography Language ${ }^{23}$ is another example of their publications. It contains brief and concise definitions of photographic terms including both trademark and generic terms, although it does not include film or camera brand names. There are no illustrations or photographs accompanying the text. The book is aimed at a primarily lay audience and does not include terms peripheral to the subject. The $\$ 2.95$ paper edition may be a better choice since the $\$ 12.95$ library binding did not stand up to even a small amount of handling.

Stroebel and Todd's Dictionary of Contemporary Photography ${ }^{24}$ is concerned with the current usage of words in photography, cinematography, animation, photographic engineering and science and related terms in electronics, photo-reproduction and television. Only names of 
persons, trademarks, chemical or historical terms have been omitted. Each page has two or three good quality illustrations or photographs to augment the text. The definitions, each about one paragraph, are more detailed than those in the Running Press publication.

The Focal Press is the publisher of many outstanding books, serials and reference sources in photography. Their Focal Dictionary of Photographic Technologies ${ }^{25}$ emphasizes the scientific aspects of photography and includes terms in electronics, electrostatics, magnetism and chemistry. It contains words of historical interest as well as some that are now obsolete. The definitions, accompanied by numerous graphs, formulas, line drawings and illustrations are technical and detailed in nature. This reference also includes a British Standards list relevant to photography technology, a list of international standards institutions, and symbols and abbreviations charts.

\section{Handbooks and Manuals}

These are the "how-to" and "why and when" reference sources on the various processes and techniques of photography. From loading the camera to developing the film, these works give the directions, facts and figures.

Nothing is assumed of the reader's basic knowledge of photography by Albert Gassan in his fourth edition of Handbook for Contemporary Photography. ${ }^{26}$ This is a step-by-step handbook beginning with putting camera and film together and ending with advanced techniques. Almost every page has diagrams, illustrations and black-and-white photographs to illustrate various techniques, tables and formulas. There is a good bibliography of "reasonably" available monographic and journal articles on various processes, history and aesthetics.

The Photographer's Handbook ${ }^{27}$ is an excellent and comprehensive guide to cameras, lenses, exposure meters, lighting and other equipment. Chapters cover darkroom techniques, composition, storage and display, controlling movement and fault analysis. Each of the encyclopedia-like sections has many subdivisions which appear in bold print at the head of each page. Each term or process is accompanied by diagrams, illustrations and black-and-white or color photographs. There is also a 25-page glossary which is profusely illustrated. Each page of the handbook is devoted to a maximum of two or three topics. Included is an alphabetical index and detailed formulas for mixing developers, toners and reducers.

How to Select and Use Photographic Materials and Processes ${ }^{28}$ tells the user how to do just that. It is divided into three basic sections: materials, processing and developing, and techniques. Almost every film available in the United States is entered alphabetically in the first section under brand name. The film's speed, grain, characteristics, developers, size, features, availability and general notes are included. Section 2 notes the description, usage, temperature range, expected results, fixers, washing agents, printing conditioners and toners of the processes, toners and developers. Finally, the techniques section describes materials, equipment and methods as well as performance tests. There are many illustrations and black-and-white photographs, a list of photographic manufacturers and distributors, and an alphabetic index. 


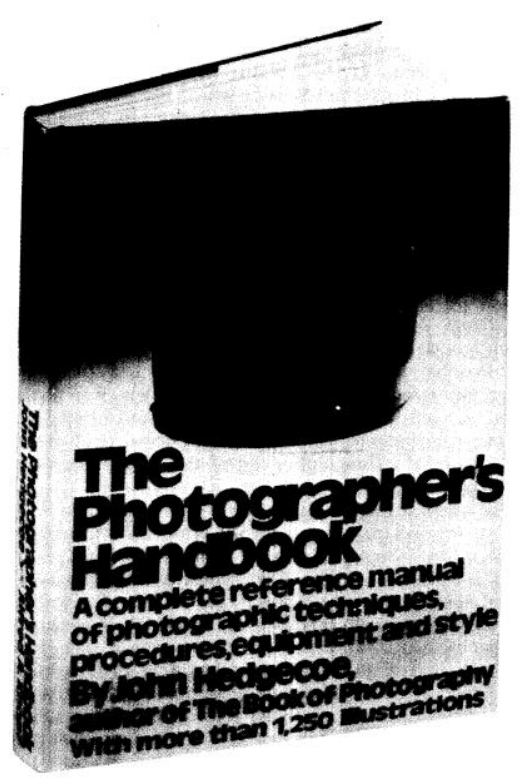

Now in its fifth edition, Photographic Lab Handbook ${ }^{29}$ contains ten sections: black-and-white film, color film, photographic papers, black-and-white processing, color processing, motion pictures and slides, optics, miscellaneous data, graphic arts materials and a general alphabetic index. Tables of temperature, conversion facts, measurements, flash data, meter speeds, and other data are included as well as most of the information described in How to Select and Use .... Each of the sections has a long and detailed introduction. The subjects are arranged in tabular form and each film, plate or paper is covered on a single page. There are no illustrations or photographs. This is a standard photography reference source and should be in every collection.

Another book of this type is Professional Photographer's Handbook. ${ }^{30}$ It is literally a handbook since it is only 3 by 7 inches. Its purpose is to provide quick reference on statistics, charts and formulas for the photographer out in the field on such items as exposure, filters, light sources, focal lengths and electronic flash. Each set of statistics is on a separate page of this colorfully printed spiral notebook binder. There is a table of contents but no index.

John S. Carroll is the latest editor and reviser of Photographic Facts and Formulas ${ }^{31}$ which is "probably the oldest photographic compendium still in active use." Originally issued in 1903 as Facts and Formulae, other editions have been published in 1924, 1940 and 1947 with a different editor each time. The emphasis is on formulas and their production for use in both new processes and in methods for which materials are still available or could be made to work. It contains many symbolic tables, weights of important compounds, atomic weights and a chart of the common names of chemicals. Each measure is quoted in both U.S. and metric weights. This is an excellent and standard source for all photography collections.

Based upon the 1965 Photography for Scientific Publication, the Handbook for Scientific Photography ${ }^{32}$ has been completely revised and expanded. The editor, Alfred Blaker, assumes that the reader knows the fundamentals of photography. The theme of this book concerns the techniques and problems associated with photographing, copying, developing and printing of still photographs in scientific research. The source includes 65 black-and-white drawings, 50 black-and-white plates and eight color plates. Opposite each plate is the subject, background used, preservation methods, lighting, size reduction, name of original photographer, filter techniques 
and stain associated with the scientifically oriented photograph. There is a good bibliography and a subject index.

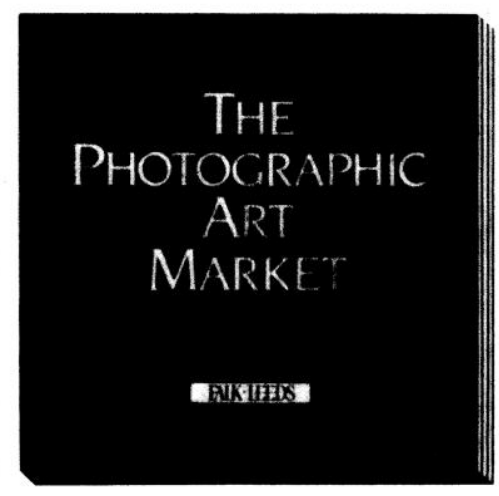

\section{Collectors and Collecting}

One of the most significant of the newer trends in photography is the collecting of photography in both private homes and galleries with a concurrent build up of interest in photography sale and photographic collection methods. This recent interest is reflected in the current copyright dates on the two sources in this section of the survey.

The most current source in this entire survey is a publication called Photographic Art Market ${ }^{33}$ which supplies statistics, charts and analyses of the auction market for photographs. Approximately half of the first edition is composed of a section called Auction Price Results for 1980/81 listing auction prices for the October to May season in North America.

Arranged by photographer, each entry contains title of piece or description, date of auction, edition size, lot number, dimensions, auction house, type of print or negative, print date, identification marks/signature and the auction price result. Six major auction houses including Christie, Phillips, Sothebys and Swann are included. There are over 4,000 entries. According to its publisher, it is to be published twice a year in two or three parts. The second issue was scheduled for March 1982.

No photography reference collection would be complete without a copy of the Photograph Collector's Guide 34 edited by Lee D. Witkin and Barbara London. Witkin is founder and owner of the Witkin Gallery in New York City. The guide is an outstanding reference source offering several special features. One is a chronology of photography which begins in 4 B.C. with a reference in literature to a pinhole (lens) forming an image. This chronology includes photographs that are representative of the events cited. The most significant section is a list of 234 individual photographers and themes, movements and organizations in photography. Each individual is entered under name or pseudonym and data concerning dates, country of major activity or residence, a narrative summary of the artist's life and career, subjects, processes employed, type of negatives used, signature, size, format, availability, price range, source or sources, agents, galleries, reproduction of signature or logo and information about portfolios are included. This list contains names of both current and historical figures. The heavily illustrated pages also include a 
selected bibliography, a list of limited editions, an arrangement by category of photographic shows that have been held recently, an international list of galleries and museums, and a glossary of terms of interest to photographic collectors.

\section{Yearbooks}

While many of the photography reference sources already described are published annually, the four titles in this section are yearbooks devoted exclusively to carefully selected photographs and not to photographers or their processes, techniques or equipment.

Now in its 45th year, Photography Year Book ${ }^{35}$ is published in England although it began as a German publication. It still has an alternate German title, Internationales Jahrbuch der Fotographie. All of the text is translated into English, German, Dutch, Spanish and French. Photographs representing the best of the year's work in all areas, schools, and types of photography except science are featured. More than three quarters of the book is devoted to the full-page reproduction of the black-and-white or color photographs accompanied only by the name of the photographer. A Technical Data section is in the rear of the book. Arranged in order of appearance, this section includes information concerning the camera used, lens, exposure and film as well as a two or three sentence description of the photograph and its subject. Twenty-nine countries are represented in the 1981 volume with the majority of submissions from the United Kingdom.

Time-Life Books is the publisher of Photography Year. ${ }^{36}$ It too is composed of photographs that reveal trends in photography. However, its selections represent items from worldwide photography projects, major exhibitions held in the United States and award winners. There is not much text; however, it does feature a bibliography of new books, some obituary notices and separate indexes to awards, photographers and studios. Each photograph is accompanied by the photographer's name, title or subject, year taken and a brief description.

Almost 300 photographs that have appeared in magazines, newspapers and on television news programs are reproduced in Best of Photojournalism ${ }^{37}$ All were winners in the Annual Pictures of the Year competition sponsored by Nikon. Divided into such categories as Best of the Best, People, Feature Stories, and Sports, the photos are accompanied by comments made by the contest panel. There is also a list of winners arranged by category and an index to photographers.

Advertising is the theme of Photographis: The International Annual of Advertising and Editorial Photography. ${ }^{38,}$ It is published by Graphis, a Swiss press that produces many other annuals and journals in the graphic arts. Photographis is divided by type of assignment: advertisements, television, calendars, annuals and reports, magazine covers, editorials, and so on. The one to four excellent quality reproductions per page are described in the English, German and French text. There are six indexes: photographers, designers, art directors, agencies, publishers, and advertisers.

\section{Miscellaneous}

The Wolfman Report on the Photographic Industry in the United States ${ }^{39}$ has been prepared by Augustus Wolfman for 27 years. It is a review and analysis of the entire photographic industry complete with over 150 charts, graphs and statistical surveys of such topics as growth patterns, consumer spending, photo products, photo retailing, photo finishing, imports and exports, 
shipment of flash bulbs and photographic prices. Most of the statistics cover eight to ten years. While there is no index, there is a very detailed classified contents section.

While all the books in this survey contain a variety of important and useful information or striking photographs, only this last source was obviously written to provide information in a somewhat light-hearted manner that makes its perusal fun. Photography Catalog: A Source Book of the Best Equipment, Materials and Photographic Resources ${ }^{40}$ can be compared in its style, format and contents to the Whole Earth Catalog. It offers page after page of diagrams and illustrations, addresses, criticism and pertinent information on new and used photography equipment, materials, film, and special processes. Each piece of photography equipment and its specifications are described and outlined. Schools of photography, workshops, picture source agencies, art galleries, "collectible" photography books, and archives are covered. While the information from this 1976 publication cannot be used for prices, anyone just interested in reading about photography or finding out more about it would find this a joy.

\section{Conclusion}

A careful reader will be aware that not one single encyclopedia or solely biographical source was included. While many fine encyclopedias have been published in the past, this reviewer could find none in print. According to a Focal Press spokesperson, the announced 1980 edition of the Focal Encyclopedia of Photography, an update of its excellent 1969 predecessor, does not even exist. A biographical source proved equally elusive.

While this has been a selective rather than a comprehensive survey of reference sources in photography, it reveals the wide scope of this interesting subject. The list is sure to widen and grow in the next few years.

\section{NOTES}

1. Albert Boni. Photographic Literature, 1960-1970. v. 2. Dobbs Ferry, NY: Morgan \& Morgan, 1972. \$35.00. 500p. LC 72-78033. ISBN 0-87100-050-4.

2. German Photographic Literature, 1839-1978: Theory, Technology, Visual: A Classified Bibliography of German-

Language Photographic Publications. Die Deutsche Photoliterature, 1839-1978: Theorie, Technik, Bild-leistungen: Eine Deutschsprachigen Photoliterature. Ed. by Frank Heidtmann, et al. New York: K.G. Saur, 1980. \$85.00. 690p. LC 80-481477. ISBN 3-598-10026-4.

3. Art, Design, Photo. 1972- . A. \$61.00. Ed. by Alexander Davis. Alexander Davis, 43 South Hill Road, Hemel, Hempstead, Hertsfordshire, HP1 1JB, England. Also distributed by Art Book Company, 18 Endell Street, London, WC2 H9BD, England. LC 76-640513. ISSN 0306-817X. ISBN 0-903-90403-9.

4. Arts in America: A Bibliography. Ed. by Bernard Karpel. Washington, DC: Smithsonian Institution Press, 1979. $\$ 190.00 /$ set. LC 79-15321. ISBN 0-87474-578-0.

5. Thomas W. Orth. A Selected Bibliography on Photographic Conservation: January 1975-December 1978. Graphic Arts Research Center, Rochester Institute of Technology, One Lomb Memorial Drive, Rochester, NY 14623. 1979? \$10.00. (Bibliography No. 39119.) 8p.

6. M. Susan Barger. Bibliography of Photographic Processes in Use before 1880: Their Materials, Processing and Conservation. Graphic Arts Research Center, Rochester Institute of Technology, One Lomb Memorial Drive, Rochester, NY 14623. 1980. \$37.50. 160p. LC 80-84390. ISBN 0-89938-003-4.

7. Art Index. 1929- . Annual accumulation. Service basis. H.W. Wilson Company. LC 31-7513. ISSN 0004-3222. 
8. Index to Articles on Photography. 1977- . A. Ed. by William S. Johnson. Visual Studies Workshop Press, 31 Prince Street, Rochester, NY 14607. \$30.00. 10\% discount to libraries. LC 79-5666. ISBN 0-89822-010. ISSN 0162-8313.

9. Photography Index: A Guide to Reproductions. Comp. by Pamela Jeffcott Parry. Westport, CT: Greenwood Press, 1979. \$29.95. 372p. LC 78-26897. ISBN 0-313-20700-3.

10. Martha Moss. Photography Books Index: A Subject Guide to Photo Anthologies. Metuchen, NJ: Scarecrow Press, 1980. \$15.00. LC 79-26938. ISBN 0-8108-1283-5.

11. The Life Library of Photography. Series published by Time-Life Books, Alexandria, VA. Revised edition, 1982-.

12. Photographer's Market. 1978- . A. \$14.95. Cincinnati: Writer's Digest Books. LC 78-643526. ISSN 0147-247X.

13. Photography Market Place: The Complete Source Bookfor Still Photography. 2d ed. Ed. by Fred W. McDarrah. New York: Bowker, 1977. \$16.95. 502p. LC 75-833. ISBN 0-8352-0922-9.

14. T.J. Marino and Don Sheff. Freelance Photographer's Handbook. New York: Bobbs-Merrill, 1980. \$8.95. pa. 135p. LC 79-6821. ISBN 0-672-52634-4.

15. Writer's and Photographer's Guide: Travel, Leisure, Sports, Outdoors, Nature. Ed. by C. Richard Ogden. San Francisco: Clarence House, 1979. \$13.75. pa. LC

79-50000. ISBN 0-933810-01-6. Festivals and Events Supplement. \$2.25. ISBN 0-933810-03-2. Parks and Forests Supplement. \$2.00. ISBN 0-933810-02-4.

16. Working Press of the Nation. 1949- . A. Published in 5 v. National Research Bureau, Inc., 310 S. Michigan Avenue, Chicago, IL 60604. \$198.00/set. \$71.00/vol. LC 46-7041. ISSN 0084-1323.

17. Literary Market Place. 1940-. A. New York, Bowker, \$32.50. pa. LC 41-51571. ISBN 0-8352-1324-2. ISSN 0075-9899.

18. American Showcase of Photography, Illustration and Graphic Design. Ed. by Tennyson Schad and Ira Shapiro. New York: American Showcase. Distributed by W.H. Smith Publishers, Inc., 112 Madison Avenue, New York, NY 10016. \$35.00. 266p. LC 77-93970. ISBN 0-931144-04-3.

19. Max Lent and Tina Lent. Photography Galleries and Selected Museums: A Survey and International Directory. Garlic Press, 533 Rialto Avenue, Venice, CA 90291. 1978. \$12.00. pa. LC 78-69605. ISBN 0-932798-00-4.

20. Gadney's Guide to 1800 International Contests, Festivals \& Grants in Film, Video, Photography, TV-Radio Broadcasting, Writing, Poetry, Play writing and Journalism. Ed. by Alan Gadney. Festival Publications, Box 10180, Glendale, CA 91209. 1979. \$22.95 cloth; \$15.95 pa. 578p. LC 77-89041. ISBN 0-930828-01-1;0-930828-00-3 pa.

21. Free Stock Photography Directory, 1979/1980. Info-sources Business Publications, 1600 Parkway East, Allen-town, PA 18103. 1979. \$10.00 pa; foreign \$15.00. 36p. ISSN 0190-1567.

22. The Photography A-V Program Directory. Ed. by A.D. Coleman. Photography Media Institute, P.O. Box 78, Staten Island, NY 10304. \$24.50. 224p. LC 80-83469. ISBN 0-936524-00-6.

23. Mary Harwood. Running Press Glossary of Photography Language. Philadelphia, Running Press, 1978. LC 77-12760. \$12.90 lib. bdg.; \$2.95 pa. ISBN 0-89471-025-7; 0-89471-024-9 pa.

24. Leslie D. Stroebel and Hollis N. Todd. Dictionary of Contemporary Photography. Dobbs Ferry, NY: Morgan \& Morgan, 1974. \$20.00. 217p. LC 73-93536. ISBN 0-87100-065-2.

25. O.A. Spencer. Focal Dictionary of Photographic Technologies. New York: Focal Press, 1973. \$39.95. 725p. ISBN 0-240-50747-9.

26. Arnold Gassan. Handbook for Contemporary Photography. 4th ed. Rochester, NY: Light Impressions, 1977.

LC 77-14576. 257p. \$14.95 cloth; \$8.95 pa. ISBN 0-87992-009-2;0-87992-008-4 pa.

27. John Hedgecoe. Photographer's Handbook: A Complete Reference Manual of Techniques, Procedures, Equipment and Style. 1st American ed. New York: Knopf, 1977. \$17.95. 352p. LC 77-74981. ISBN 0-394-40754-7.

28. David Brooks. How to Select \& Use Photographic Materials and Processes. H.P. Books, P.O. Box 5367, Tucson,

AZ 85703. 1979. \$7.95. pa. LC 79-91000. ISBN 0»89586-032-5.

29. John S. Carroll. Photographic Lab Handbook. 5th ed. New York: Amphoto, 1979. LC 74-84030. \$24.95 cloth; $\$ 12.95$ pa. 656p. ISBN 0-8174-2486-5; 0-8174-2158-0 pa.

30. Larry I. Logan. Professional Photographer's Handbook. Logan Design Group, 6101 Melrose Avenue, Los Angeles, CA 90038. 1980. \$14.95. pa. 128p. LC 80-80056. ISBN 0-9603856-0-6.

31. Edward John Wall. Photographic Facts and Formulas. Rev. and extensively rewritten by John S. Carroll. New York: Amphoto, 1975. \$12.95. pa. 480p. LC 73-92418. ISBN 0-8184-2193-9. 
32. Alfred A. Blaker. Handbook for Scientific Photography. San Francisco, CA, W.H. Freeman, 1977. \$28.95. 319p. LC 77-24661. ISBN 0-7167-0285-1.

33. Photographic Art Market. 1981- . Published twice a year in two or three parts. Falk-Leeds International, Inc., 521 West 23rd St., New York, NY 10011. \$29.95. LC 81-68613. ISBN 0-940926-00-8.

34. Lee D. Witkin and Barbara London. The Photograph Collector's Guide. New York: New York Graphic Society, 1979. \$32.50. 438p. LC 79-17019. ISBN 0-8212-0681-8.

35. Photography Yearbook, 1981. A. Ed. by R.H. Mason, Fountain Press, Argus Books, Ltd., Station Road, Kings Langley, Herfordshire, England. 1980. \$31.00. 271p. LC 36-13575. ISBN 0-85242-732-8.

36. Photography Year, 1981. A. New York, Time-Life Books, 1981. \$12.95. 256p. LC 72-91518. ISSN 0090-4406. 37. Best of Photojournalism, 5. University of Missouri Press, 200 Lewis, Columbia, MO 65211. 1980. \$24.95. (University of Missouri Journalism School Series.) 256p. LC 77-081586. ISBN 0-88225-263-1. ISSN 0161-4762. 38. Photographis: The International Annual of Advertising and Editorial Photography, 1981. A. Ed. by Walter Her-deg. Graphis Press, Corporation, 107 Dofourstrasse CH-8008, Zurich, Switzerland. Distributed by Hastings House. 1981. \$49.50. (Visual Communication Books Publication No. 163.) 236p. ISBN 3-85709-281-5. 39. Wolfman Report on the Photographic Industry in the United States. A. ABC Leisure Magazines, Inc., 825 Seventh Avenue, New York, NY 10019. 1979. \$75.00. 1OOp. LC 70-6042. ISSN 0084-103X.

40. Photography Catalog. Ed. by Norman Snyder and others. New York: Harper \& Row, 1976. \$7.95. 256p. LC 76-9202. ISBN 0-06-013979-X. 